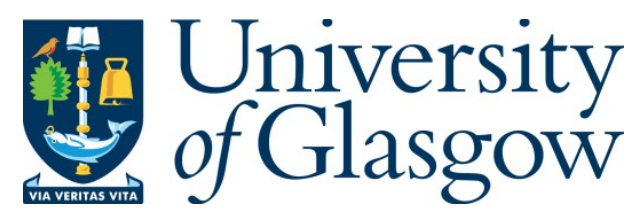

Gherghina, S. and Grad, M. (2021) Political game-changers: the importance of leaders for newly emerged parties in Romania. Slavic Review, 80(3), pp. 608-628.

(doi: $10.1017 /$ slr.2021.146)

This is the Author Accepted Manuscript.

There may be differences between this version and the published version. You are advised to consult the publisher's version if you wish to cite from it.

http://eprints.gla.ac.uk/241345/

Deposited on: 13 December 2021

Enlighten - Research publications by members of the University of Glasgow http://eprints.gla.ac.uk 


\title{
Political Game-Changers: The Importance of Leaders for Newly Emerged Parties in Romania
}

\author{
Sergiu Gherghina \\ Department of Politics and International Relations \\ University of Glasgow \\ Marius Grad \\ Department of International Studies and Contemporary History \\ Babes-Bolyai University Cluj
}

\begin{abstract}
Party leaders continue to be crucial players in politics. The theories of personalization and presidentialization of party politics reflect the centrality of leaders' roles. Little attention has been paid about the effects of leaders on the formation and development of newly emerged parties. This article aims to fill that gap and analyzes the effect of leaders on formation, intraparty cohesion and membership organization of three newly emerged Romanian parties between 2015 and 2019. The qualitative analysis uses content from primary (party documents and elite discourses) and secondary sources (media reports). The findings indicate that the leaders' approaches towards party formation and organization differ substantially across the examined parties and have long-lasting effects on their survival on the political scene.
\end{abstract}

Keywords: political parties, leaders, party formation, cohesion, membership

\section{Introduction}

The political scene of many East European countries has been recently flooded by newly emerged parties. These parties rarely have similar ideological profiles, electoral strategies or behavior once in parliament. One of their few shared features is the prominence of party leaders. Earlier research shows the general importance of party leaders for their parties, both externally and internally in new and established democracies. ${ }^{1}$ Externally, the leaders engage in direct communication with the electorate, become the face that voters can identify with

\footnotetext{
1 Jean-Benoit Pilet and William Cross, eds., The Selection of Political Party Leaders in Contemporary Parliamentary Democracies (London: Routledge, 2014); Elisabeth Gidengil and André Blais, “Are Party Leaders Becoming More Important To Vote Choice in Canada?," in Political Leadership and Representation in Canada: Essays in Honour of John C. Courtney, ed. Hans J. Michelmann, Donald C. Story, and Jeffrey S. Steeves (Toronto: University of Toronto Press, 2007), 39-59; Bernadette C. Hayes and Ian McAllister, "Gender, Patry Leaders, and Election: Outcomes in Australia, Britain, and the United States," Comparative Political Studies 30, no. 1 (1997): 3-26; Fortunato Musella, Political Leaders Beyond Party Politics (Basingstoke: Palgrave Macmillan, 2018); Sergiu Gherghina, ed., Party Leaders in Eastern Europe: Personality, Behavior and Consequences (Basingstoke: Palgrave Macmillan, 2020).
} 
the party and thus occupy the center stage in most elections. ${ }^{2}$ Internally, the leaders can have an impact on a series of features that ensures the survival of party organization. Among these, the most common are the general political strategies and policies, the appointments to the party executive office, and some of the candidate selection for public office. ${ }^{3}$ The party organization is of particular importance for the electoral performance and long-term survival of parties, especially in post-communist Europe. ${ }^{4}$ As such, it is not surprising that much of leaders' actions are oriented towards internal reforms of the party organization. They are also important drivers of institutional change within their parties. A change in leadership can mean the implementation of new strategies, consistent with the values of the new leader, often leading to the change of the status quo. ${ }^{5}$

This central role of party leaders has generated extensive scholarly interest in the effects of leadership styles on the development of party organizations. So far, most studies reflect the centrality of leaders in established political parties in Eastern Europe. Far little attention has been paid to the effects of leaders on the formation and development of newly created parties. Earlier studies emphasize the importance of newly created parties for the political arena in the region, where some achieved important electoral success or entered government coalitions. ${ }^{6}$ These studies touch upon the importance of leaders in party development but not always systematically. Other works focus explicitly on the roles of

\footnotetext{
${ }^{2}$ Thomas Poguntke, "Party Organizational Linkage: Parties Without Firm Social Roots?," in Political Parties in the New Europe, ed. Kurt Richard Luther and Ferdinand Muller-Rommel (Oxford: Oxford University Press, 2002), 4362; Amanda Bittner, Platform or Personality? The Role of Party Leaders in Elections (Oxford: Oxford University Press, 2011); Ludger Helms, ed., Comparative Political Leadership (Basingstoke: Palgrave Macmillan, 2012).

3 Jean Blondel and Jean-Louis Thiébault, Political Leadership, Parties and Citizens: The Personalisation of Leadership (New York: Routledge, 2010); Reuven Y. Hazan and Gideon Rahat, Democracy within Parties. Candidate Selection Methods and Their Political Consequences (Oxford: Oxford University Press, 2010).

${ }^{4}$ Margit Tavits, "Party Organizational Strength and Party Unity in Post-Communist Europe," European Political Science Review 4, no. 3 (2012): 409-31; Margit Tavits, Post-Communist Democracies and Party Organization (Cambridge: Cambridge University Press, 2013); Sergiu Gherghina, Party Organization and Electoral Volatility in Central and Eastern Europe: Enhancing Voter Loyalty (London: Routledge, 2014).

${ }^{5}$ Robert Harmel et al., "Performance, Leadership, Factions and Party Change: An Empirical Analysis," West European Politics 18, no. 1 (1995): 1-33; William Cross and Jean-Benoit Pilet, eds., The Politics of Party Leadership: A Cross-National Perspective (Oxford: Oxford University Press, 2016).

${ }^{6}$ Seán Hanley, "Dynamics of New Party Formation in the Czech Republic 1996-2010: Looking for the Origins of a 'Political Earthquake,'” East European Politics 28, no. 2 (2012): 119-43; Boris Gurov and Emilia Zankina, "Populism and the Construction of Political Charisma. Post-Transition Politics in Bulgaria," Problems of PostCommunism 60, no. 1 (2013): 3-17; Sarah Engler, "Corruption and Electoral Support for New Political Parties in Central and Eastern Europe," West European Politics 39, no. 2 (2016): 278-304; Alenka Krašovec, "A Hint at Entrepreneurial Parties? The Case of Four New Successful Parties in Slovenia," Czech Journal of Political Science 24, no. 2 (2017): 158-78; Vlastimil Havlik and Petr Voda, "Cleavages, Protest or Voting for Hope? The Rise of Centrist Populist Parties in the Czech Republic," Swiss Political Science Review 24, no. 2 (2018): 161-86.
} 
leaders for the development of their parties, but they do it either for specific types of parties (business-firm) or for particular ideologies. ${ }^{7}$ As such, the role of leaders for newly emerged parties remains largely unclear. To address this gap in the literature, our article aims to assess the impact of leadership on three components of party organization: party formation, intraparty cohesion and the membership organization. We argue and test, on the basis of insights from the literature on new parties and party organizations, the extent to which features such as personalization, presidentialization, need for power, and the political experience of the leader can make an impact.

To this end, we analyze the effects produced by the first leaders of three newly emerged (non-business-firm) parties from the same political system between 2015 and $2019 .^{8}$ The first party leaders are the appropriate unit of analysis since we seek to understand three components of party organization that are usually established when the party is formed. As such, the leadership at the moment of formation is crucial. The study closely investigates three political parties in Romania: Alliance of Liberals and Democrats (ALDE), People's Movement Party (PMP) and Save Romania Union (USR). Their selection is done to maximize variation across several criteria such as formation, electoral performance, ideology and role in government (vs. opposition). For example, in terms of electoral performance, in the 2019 European elections, ALDE lost some of its electoral support (relative to 2016), PMP was fairly stable, while USR gained more support in the context of joining forces with another party emerged in 2018. In defining a new party, this article uses four criteria proposed in the literature: running for the first time in elections, a new label, no more than half of its top candidates originate from a single former party, and they do not originate from a split. ${ }^{9}$

\footnotetext{
7 Lubomír Kopeček, "II'm Paying, So I Decide'. Czech ANO as an Extreme Form of a Business-Firm Party," East European Politics and Societies 30, no. 4 (2016): 725-49; Sergiu Gherghina and Sorina Soare, "Electoral Performance beyond Leaders? The Organization of Populist Parties in Postcommunist Europe," Party Politics, no. online first (2019).

${ }^{8}$ Thre are two reasons for which we do not include the People's Party Dan Diaconescu (PPDD) - the other newly emerged party that gained parliamentary represnetation in the last two decades - in the analysis. First, the party emerged before the 2012 elections and did not compete with the three that we compare because it was disintegrated until the 2016 elections. Second, the party resembles a business-firm party and that is a specific genre that may not be comparable with the others. For details about the PPDD characteristics, see Sergiu Gherghina and Sorina Soare, "From TV to Parliament: The Successful Birth and Progressive Death of a Personal Party the Case of the People's Party Dan Diaconescu," Czech Journal of Political Science 24, no. 2 (2017): 20120.

${ }^{9}$ Simon Hug, Altering Party Systems: Strategic Behavior and the Emergence of New Political Parties in Western Europe (Ann Arbor: University of Michigan Press, 2001); Allan Sikk, "How Unstable? Volatility and the Genuinely New Parties in Eastern Europe," European Journal of Political Research 44, no. 3 (May 2005): 391-412; Shlomit Barnea and Gideon Rahat, "'Out with the Old, in with the "'New'"': What Constitutes a New Party?," Party Politics
} 
We focus on Romania due to its party system dynamics, which makes it the least likely case for new parties to gain parliamentary representation. For two decades, between 1992 and 2012, no new political party gained parliamentary representation on their own; in this time frame only one minor party gained seats running in electoral alliances. The parliamentary arena was divided between a handful of actors, which alternated government and opposition. This cartelization of politics continued in 2012 because the newly formed People's Party Dan Diaconescu (PPDD) was a conglomerate of former parliamentarians from other parties. ${ }^{10}$ The breakthrough of newly formed parties took place in 2016, with the parliamentary representation of the three parties included in this study. Their selection for analysis is based on the above-mentioned criterion: they are the first newly emerged parties to gain parliamentary representation running on their own since 1992 in a hostile environment. The analysis of this critical case can inform about how the leaders shape the formation and development of their political parties on a barren soil. The qualitative analysis of this article uses content from primary (party documents and elite discourses) and secondary sources (media reports).

The remainder of this article is structured as follows. The first section reviews the literature about the leaders of newly emerged parties. This is followed by a brief discussion regarding the data and method used in the analysis, while the third section provides an overview of the three parties analyzed in this article. The next three sections focus on the effects of leaders on party formation, intra-party cohesion and membership organizations. The last section includes a comparative discussion of the findings and the main implications for the broader study of party leadership.

\section{Leaders and their Effects on Party Organization}

Previous studies show how leaders' traits and behaviors can leave a mark on the party organization. There is a variety of traits behind the effect of a party leader. For example, one strand of literature refers to the uncertainty in office as a cause for the organizational change. The party leaders do not know how long they will be in office, how many times they will be

17, no. 3 (2011): 303-20; Krystyna Litton, "Party Novelty: Conceptualization and Measurement of Party Change," Party Politics 21, no. 5 (2015): 712-25. The definition that we use here correpsonds to what Litton calls the thin conceptualization of novelty.

${ }^{10}$ Sergiu Gherghina, "Rewarding the 'Traitors'? Legislative Defection and Re-Election in Romania," Party Politics 22, no. 4 (2016): 490-500. 
re-elected, what extraordinary situations may occur (e.g. they are usually removed from office after losing elections) and thus they seek to shape the organization as soon as they have the possibility. ${ }^{11}$ Another strand of literature refers to leaders' specific set of abilities that is be reflected in the development of party organization and proposed changes. While it is common for new leaders to use organizational innovation as part of their strategy to consolidate power ${ }^{12}$, the ways in which they do so and what elements are changed differ considerably. Another body of research points in the direction of personality traits and leadership styles that can produce changes in the organization. Such traits vary from charisma (e.g. the Charismatic Leadership Theory), competence or integrity to cognitive complexity, intelligence (e.g. the Cognitive Resource Theory), experience or policy expertise. ${ }^{13}$

This article focuses on newly emerged political parties and on their first leaders. Under these circumstances, many of the traits related to policy or behavior in office are not applicable. Instead, these parties could benefit from visible and strong leaders who can appeal to voters and increase parties' electoral performance. Two contemporary theories the personalization and presidentialization of party politics - provide several important arguments that we consider to be applicable to the cases of new parties. Empirical evidence regarding the existence of these two processes comes from various political systems and types of parties in the last three decades. ${ }^{14}$ The following sub-section argues that the desire

\footnotetext{
${ }^{11}$ Harmel et al., "Performance, Leadership, Factions and Party Change: An Empirical Analysis"; Cross and Pilet, The Politics of Party Leadership: A Cross-National Perspective.

${ }^{12}$ Angelo Panebianco, Political Parties: Organization and Power (Cambridge: Cambridge University Press, 1988).

${ }^{13}$ Robert J. House, William D. Spangler, and James Woycke, "Personality and Charisma in the U.S. Presidency: A Psychological Theory of Leader Effectiveness," Administrative Science Quarterly 36, no. 3 (1991): 364-96; Fred E. Fiedler, "Cognitive Resources and Leadership Performance," Applied Psychology 44, no. 1 (1995): 5-28; Stephen Benedict Dyson and Thomas Preston, "Individual Characteristics of Political Leaders and the Use of Analogy in Foreign Policy Decision Making," Political Psychology 27, no. 2 (2006): 265-88; Gherghina, Party Leaders in Eastern Europe: Personality, Behavior and Consequences.

${ }^{14}$ Clive Bean, "The Electoral Influence of Party Leader Images in Australia and New Zealand," Comparative Political Studies 26, no. 1 (1993): 111-32; Thomas Poguntke and Paul Webb, eds., The Presidentialization of Politics: A Comparative Study of Modern Democracies (Oxford: Oxford University Press, 2005); Anthony Mughan, Media and the Presidentialization of Parliamentary Elections (Basingstoke: Macmillan, 2000); Paul Webb, Thomas Poguntke, and Robin Kolodny, "The Presidentialization of Party Leadership? Evaluating Party Leadership and Party Government in the Democratic World," in Comparative Political Leadership, ed. Ludger Helms (Basingstoke: Palgrave Macmillan, 2012), 77-98; Clive Bean and Anthony Mughan, "Leadership Effects in Parliamentary Elections in Australia and Britain," American Political Science Review 83, no. 4 (1989): 1165-79; Ellis S. Krauss and Benjamin Nyblade, "'Presidentialization' in Japan? The Prime Minister, Media and Elections in Japan," British Journal of Political Science 35, no. 2 (2005): 357-68; Gideon Rahat and Ofer Kenig, From Party Politics to Personalized Politics? Party Change and Political Personalization in Democracies (Oxford: Oxford University Press, 2018); Marina Costa Lobo, "Parties and Leader Effects," Party Politics 14, no. 3 (2008): 281-98; Bittner, Platform or Personality? The Role of Party Leaders in Elections.
} 
to personalize the party, the presidentialization tendency with emphasis on holding control, and the political experience of the leader are features that can produce impact on the party organization.

\section{Three Features of Party Leaders}

The personalization of party leadership refers to the situation in which individual party leaders and their personalities are prominent in politics at the expense of parties and collective identities. ${ }^{15}$ This has been studied extensively in relationship to citizens' perceptions of politics and voters' electoral choices. The key argument here is that the leaders can mobilize voters through their image, abilities and personality traits. ${ }^{16}$ This is particularly relevant in the context of weaker partisan loyalties where voters lack party cues and may turn to leaders to decide their vote. ${ }^{17}$ The mobilizing role of the party leader is crucial for newly emerged parties, which have only few candidates that are already familiar to voters. The latter usually know only the leader, who can thus shape voting preferences much more than in established parties. $^{18}$

In addition to this direct effect, there is also a possibility of an indirect impact of leader personalization on the electorate through the party. ${ }^{19}$ In the case of established parties, the leader popularity is reinforced by the party popularity, the two can hardly be separated in the minds of the voters. ${ }^{20}$ One way through which political parties succeed in stabilizing the electoral preferences of their voters is through the re-nomination of a high number of

\footnotetext{
${ }^{15}$ Much of the existing literature looks at the presidentialization and personalization as a move towards a stronger role of the leader within existing parties. See, for example, Lauri Karvonen, The Personalisation of Politics. A Study of Parliamentary Democracies (Colchester: ECPR Press, 2010); Gideon Rahat and Tamir Sheafer, "The Personalization(s) of Politics: Israel, 1949-2003," Political Communication 24, no. 1 (2007): 65-80. In this article, the agrument is not about such a process but more about the characteristics at the point of foundation. ${ }^{16}$ Marina Costa Lobo and John Curtice, Personality Politics? The Role of Leader Evaluations in Democratic Elections (Oxford: Oxford University Press, 2015); Alan Renwick and Jean-Benoit Pilet, Faces on the Ballot. The Personalization of Electoral Systems in Europe (Oxford: Oxford University Press, 2016).

${ }^{17}$ Ian McAllister, "The Personalization of Politics," in The Oxford Handbook of Political Behavior, ed. Russell. J. Dalton and Hans-Dieter Klingemann (Oxford: Oxford University Press, 2007), 571-78.

${ }^{18}$ Bram Wauters et al., "Centralized Personalization at the Expense of Decentralized Personalization. The Decline of Preferential Voting in Belgium (2003-2014)," Party Politics 24, no. 5 (2018): 511-23.

${ }^{19}$ Mughan, Media and the Presidentialization of Parliamentary Elections; Blondel and Thiébault, Political Leadership, Parties and Citizens: The Personalisation of Leadership.

${ }^{20}$ Joop J. M. van Holsteyn and Rudy B. Andeweg, "Demoted Leaders and Exiled Candidates: Disentangling Party and Person in the Voter's Mind," Electoral Studies 29, no. 4 (2010): 628-35; Gianluca Passarelli, "Parties' Genetic Features: The Missing Link in the Presidentialization of Parties," in The Presidentialization of Political Parties: Organizations, Institutions and Leaders, ed. Gianluca Passarelli (Basingstoke: Palgrave Macmillan, 2015), 1-25.
} 
previous parliamentarians. ${ }^{21}$ The latter are highly visible politicians who benefit from extensive media coverage and the possibility to carry out constituency work as incumbents.

Contemporary parties, leaders and voters use personalization for pragmatic reasons. Political parties can promote its messages through a visible individual that voters can recognize and identify with. Party leaders are content with the control over resources and popularity they gain in that position, while voters can hold a person responsible for political actions much easier than an abstract entity. ${ }^{22}$ With all these features, the personalization of party politics is likely to have an impact on the internal and external life of parties.

The presidentialization can include or be supplementary to personalization. The two concepts present important differences both at theoretical and empirical level and should not be used interchangeably. ${ }^{23}$ The presidentialization means the embodiment of power in monocratic actors, involving leaders' control over power resources, autonomy in making decisions and a leader-centered electoral process. ${ }^{24}$ The presidentialization is a well-defined political institutional role that creates an effect both on individuals and on political parties. ${ }^{25}$ Unlike personalization, the presidentialization can alter the formal institutional structures and can do so at three levels. ${ }^{26}$

First, the elections can be leader centered. Through the mechanisms presented above for personalization, the individuals and their image lie at the core of campaign, replacing party ideology. Second, there is a verticalization or centralization of power, which flows upwards from the group to the leader ${ }^{27}$, oriented at transforming and strengthening the leverage of specific individuals. Third, the presidentialization transforms intra-party power structures by lowering the importance and influence of the traditional party units such as the parliamentary party group, delegate conventions or territorial organizations. Leaders push for autonomy at the expense of mid-level political elites. All these indicate a high desire for control and degree of involvement in the internal decision-making process, which has been referred to in the literature as the need for power. ${ }^{28}$

\footnotetext{
${ }^{21}$ Gherghina, Party Organization and Electoral Volatility in Central and Eastern Europe: Enhancing Voter Loyalty.

22 Ian McAllister, "The Personalization of Politics in Australia," Party Politics 21, no. 3 (2015): 337-45.

${ }^{23}$ Passarelli, "Parties' Genetic Features: The Missing Link in the Presidentialization of Parties."

${ }^{24}$ Poguntke and Webb, The Presidentialization of Politics: A Comparative Study of Modern Democracies.

25 Passarelli, "Parties' Genetic Features: The Missing Link in the Presidentialization of Parties."

${ }^{26}$ Poguntke and Webb, The Presidentialization of Politics: A Comparative Study of Modern Democracies.

27 Meital Balmas et al., "Two Routes to Personalized Politics," Party Politics 20, no. 1 (2014): 37-51.

${ }^{28}$ Thomas Preston, The President and His Inner Circle. Leadership Style and the Advisory Process in Foreign Policy Making (Washington DC: Columbia University Press, 2001).
} 
The third trait which is likely to influence the approach of leaders towards the party organization is the political experience. This can be in the form of general involvement in politics, occupancy of public office or even the position of party leader in other political formations. Compared to newcomers in politics, those with political experience are likely to have different views about the life and development of political parties. These differences can be visible in several areas such as the approaches towards the relationship between the units of the party (central vs. territorial branches), recruitment and selection methods, campaigning or the building of membership organization. The latter, for example, brings a series of advantages to parties: a relatively stable core of voters who do not require special effort to mobilize, a broad pool of candidate recruitment, the carriers of the party message in the electorate, and volunteers during campaigns. ${ }^{29}$

\section{The Potential Effects: Dimensions of Party Organization}

All these arguments indicate three potential avenues through which party leaders can have an impact on the party organizations. For newly emerged parties, this effect is crucial on three components: the party formation, intra-party cohesion and membership organization. This sub-section outlines the theoretical expectations regarding these potential effects. First, when forming the party, there is a choice between making it dependent on one individual and linking it to different social groups. More precisely, there are two major ways in which a political party is formed: entrepreneurial or rooted..$^{30}$ The entrepreneurial parties are formed by individuals who are not affiliated to organized groups. These individuals use the opportunities that arise mainly from the public frustration with policies (including reforms) and / or with the politicians. As outsiders to the system, the entrepreneurs build parties that can make stronger and carry on the parliamentary arena their critical discourses. This type has become increasingly popular in both established and new democracies. ${ }^{31}$

\footnotetext{
29 Susan Scarrow, Beyond Party Members. Changing Approaches to Partisan Mobilization (Oxford: Oxford University Press, 2015); Emilie van Haute and Anika Gauja, Party Members and Activists (Abingdon: Routledge, 2015); Gherghina, Party Organization and Electoral Volatility in Central and Eastern Europe: Enhancing Voter Loyalty.

${ }^{30}$ Robert Harmel and Lars Svåsand, "Party Leadership and Party Institutionalisation: Three Phases of Development," West European Politics 16, no. 2 (1993): 67-88; Elin H Allern and Tim Bale, "Political Parties and Interest Groups," Party Politics 18, no. 1 (2012): 7-25; Nicole Bolleyer and Evelyn Bytzek, "Origins of Party Formation and New Party Success in Advanced Democracies," European Journal of Political Research 52, no. 6 (2013): 773-96.

${ }^{31}$ Sikk, "How Unstable? Volatility and the Genuinely New Parties in Eastern Europe"; Grigore Pop-Eleches, "Throwing Out the Bums: Protest Voting and Anti-Establishment Parties after Communism," World Politics 62,
} 
One specific genre of the entrepreneurial avenue is the business-firm parties. The latter are built outside the political establishment by one individual who applies his / her business recipe for success to politics. Such parties are characterized by minimal bureaucracy, limited membership, emphasis on the figure of the leader and often loose ideology. ${ }^{32}$ For all parties that belong to the entrepreneurial type, the role of the leader is decisive in every single aspect of the party life. For these reasons, the parties usually disappear when the political founder withdraws from politics.

The rooted formation of parties provides leaders less avenues for direct personalization. This happens because parties emerge with resources from existing organizations or groups. Such parties include a broad variety of political actors from the political spectrum ranging from labor or religious based parties to radical right / left and niche parties (e.g. the Greens dealing with the environment, the Pirates with Internet rights and freedoms, the Pensioners' parties with elderly issues etc.). However, this does not prevent leaders to become the center of party organizations especially when leaders contribute to their creation. More precisely, the first leader of a newly emerged party has room for maneuver in deciding about how much power is concentrated in various party units and how much control over the party machinery can retain.

Second, the intra-party cohesion is a crucial element for new parties because they can collapse after early internal dissent or splits. Intra-party cohesion involves multiple dimensions and occurs at the level of several party units, e.g. the parliamentary party group, territorial branches etc. ${ }^{33}$ For this analysis, we use a unidimensional definition of intra-party cohesion and we refer to the propensity of members and leaders to hang together in a relatively monolithic structure. Intra-party cohesion is difficult to achieve through the means used by the established parties. More precisely, one source for internal cohesion is a shared

no. 2 (2010): 221-60; Duncan McDonnell, "Silvio Berlusconi's Personal Parties: From Forza Italia to the Popolo Della Libertà," Political Studies 61, no. Issue Supplement S1 (2013): 217-33; Glenn Kefford and Duncan McDonnell, "Ballots and Billions: Clive Palmer's Personal Party," Australian Journal of Political Science 51, no. 2 (2016): 183-97.

${ }^{32}$ Gherghina and Soare, "From TV to Parliament: The Successful Birth and Progressive Death of a Personal Party the Case of the People's Party Dan Diaconescu"; Jonathan Hopkin and Caterina Paolucci, "The Party as Business Firm: Cases From Spain and Italy," European Journal of Political Research 35, no. 2 (1999): 307-39; Kopeček, "I'm Paying, So I Decide'. Czech ANO as an Extreme Form of a Business-Firm Party."

${ }^{33}$ Caroline Close and Sergiu Gherghina, "Rethinking Intra-Party Cohesion: Towards a Conceptual and Analytical Framework," Party Politics 25, no. 5 (2019): 652-663. 
history of fighting against electoral opponents ${ }^{34}$, a history that enhances solidarity and loyalty to the party. The new parties lack this shared history because they have not run in previous elections. Even though some of their elites may come from different parties - as the result of party switching, split or merger - they still lack the attachment to the new party. As such, the ways in which cohesion is ensured by the leaders becomes paramount for the life of the newly created parties.

Earlier studies show how a strong leader who controls the power within the party and has a highly personalized style can be an important source of cohesion. ${ }^{35}$ The leader's popularity prevents the emergence of factions since no elite or member wishes to raise their voice against. Another way in which party leaders can ensure a high level of intra-party cohesion is through reward and punishment. For example, the leader can reward the loyal party members with higher positions in the party since advancement to such positions can be controlled by the leader. ${ }^{36}$ To avoid factionalism, the party leaders can punish those members who intend to dissent by demoting them or by withdrawing the political support. The latter is relevant for those members who occupy public offices that are tied to the election under the label of a particular party and for those members who strive for re-nomination.

Third, the newly emerged parties have fewer members compared to the already existing parties for at least four reasons. ${ }^{37}$ These are: their recent formation makes it difficult to establish solid anchors in society and thus the appeal for membership; their electoral strategies rely less on grass-roots membership and more on the use of technology (including social media) as means to reach out directly to voters; some of the newly emerged parties offer multiple modes for people engagement in party activities without formal membership ${ }^{38}$; some of the newly emerged parties have very few members due to their high personalization. ${ }^{39}$ All these indicate that the approach towards the membership organization can impact on the subsequent party development.

\footnotetext{
${ }^{34}$ Steven Levitsky and Lucan A. Way, "Beyond Patronage: Violent Struggle, Ruling Party Cohesion, and Authoritarian Durability," Perspectives on Politics 10, no. 4 (2012): 869-89; James Loxton, "Authoritarian Successor Parties," Journal of Democracy 26, no. 3 (2015): 157-70.

${ }^{35}$ Loxton, "Authoritarian Successor Parties."

${ }^{36}$ Christopher J. Kam, Party Discipline and Parliamentary Politics (Cambridge: Cambridge University Press, 2009).

${ }^{37}$ Luciano Bardi, Enrico Calossi, and Eugenio Pizzimenti, "Which Face Comes First? The Ascendancy of the Party in Public Office," in Organizing Political Parties: Representation, Participation, and Power, ed. Susan E. Scarrow, Paul D. Webb, and Thomas Poguntke (Oxford: Oxford University Press, 2017), 62-83.

38 Raul Gomez and Luis Ramiro, "The Limits of Organizational Innovation and Multi-Speed Membership: Podemos and Its New Forms of Party Membership," Party Politics 25, no. 4 (2019): 534-46.

${ }^{39}$ Kopeček, "I'm Paying, So I Decide'. Czech ANO as an Extreme Form of a Business-Firm Party."
} 


\section{An Overview of the Three Parties}

ALDE was officially formed in June 2015, after a merger between The Liberal Reformist Party (PLR) led by Calin Popescu Tăriceanu and The Conservative Party (PC) led by Daniel Constantin. The PLR was established by Tăriceanu after he resigned from PNL (The National Liberal Party). Few months later, he found an ally in the Romanian Parliament: the small PC, often present in many coalition governments due to their traditional alliance with the social democrats (PSD). After PLR and PC formed one parliamentary group, ALDE was registered as a unique political party. The entity claims a center-right ideology focused on citizens' rights and freedoms and an economic liberal approach. ${ }^{40}$ The party ran for the first time in the 2016 local elections, when it got third, with a general result of $6.32 \% .{ }^{41}$ In the same year, at the legislative elections, the party had a similar electoral support (6.01\%), which positioned ALDE on the fifth position, with the lowest electoral support among the newly formed parties.

Following the 2016 legislative elections, The Social Democrats (with $46 \%$ of the votes) needed a small coalition partner to secure parliamentary majority. They invited ALDE to join the coalition and, since then, the two parties supported three different cabinets; in each of them ALDE received four out of 26 ministers. As a result of the relatively poor performance in office and on the grounds of increasing popular discontent with the government, ALDE failed to pass the electoral threshold in the 2019 European elections. After these elections, the cooperation between the two parties (PSD-ALDE) has gradually become unstable. The arrest of the social democratic leader in the aftermath of the 2019 elections for the European Parliament and internal tensions within the coalition led to a difficult cooperation. ALDE asked for more ministers in the government and failed to agree with the social democrats on a common candidate for the 2019 presidential elections. As such, for most of its existence ALDE sought to preserve the access to power through political alliances and partnerships.

The PMP emerged from the People's Movement Foundation, formed in March 2013 as a result of an intra-party conflict within the liberal democrats (PDL), the main opposition party at the time. Two factions emerged within the PDL: one supporting the country president Traian Băsescu and one supporting the party leader Vasile Blaga. Băsescu's supporters left the party after Blaga secured a new term in office and formed the PMP in January 2014. In

\footnotetext{
${ }^{40}$ Alliance of Liberals and Democrats in Romania, ALDE Statute, 2017.

${ }^{41}$ Website of the Permanent Electoral Authority, www.aep.ro, last accessed 22 August 2019.
} 
October 2015, Băsescu joined the party after finishing his term as head of state and was elected as party leader the same month. He held this position until June 2018 when leader was elected Eugen Tomac. According to its statute and manifesto for the first legislative elections in which it ran, the PMP's ideology is a combination of social conservatism, economic liberalism and Christian democracy. ${ }^{42}$ The first electoral test was passed in the 2014 European elections (6.21\% of the votes) when the party gained the sixth place. In the 2016 local elections, the party got $4.46 \%$ of the votes and in the national legislative run it increased to roughly $5.5 \%$ as the fourth placed party. In the 2019 European elections PMP had a similar result, sufficient to have Băsescu elected as Member of the European Parliament. ${ }^{43}$

The USR was established by Nicușor Dan, well known civic activist and former candidate for mayor of Bucharest in 2012 and 2016. It represents the national evolution of a previous political project - Union Save Bucharest (USB), formed as a political party in July 2015. The civil movement and the involvement in local politics date back to 2008 when the local NGO Save Bucharest Association was launched. The evolution from local to national politics was a step taken after the success registered in the local elections of 2016 in Bucharest, were Dan got $25 \%$ of the votes, being ranked second before the candidates of several established parties. In August 2016, the USB transformed into the USR, with Dan elected as the first party leader. ${ }^{44}$ The party ideology is a mix between demand for full transparency, anti-corruption, economic liberalism and Eurofederalism. ${ }^{45}$ In the 2016 national legislative elections the party got third with $8.61 \%$ of the votes, while in the 2019 European elections, the USR formed an electoral alliance with another newly emerged party to get $22.36 \%$ of the votes.

\section{Personalization and Party Formation}

\footnotetext{
42 People's Movement Party, "PMP Fights for Romania," PMP Election Manifesto, 2016, https://pmponline.ro/alegeri-parlamentare/program-politic-de-campanie, last accessed 22 May 2017; People's Movement Party, PMP Statute, 2013.

${ }^{43}$ Both ALDE and PMP, although formed after splits from and mergers of existing parties fulfil the criteria that qualify them as new parties: they have new labels and no more than half of its top candidates (in legislative elections) originate from a single former party. The latter is an accurate reflection of reality although it may be misleading that much of the party elite is both parties come from single former parties: the PNL in the case of ALDE and the PDL in the case of the PMP.

${ }^{44}$ Gabriel Pecheanu, "Rezultatele Finale La Alegerile Locale 2016, În Bucureşti Şi În Tară (Final Results at the 2016 Local Elections, in Bucharest and in the Country)," Gandul.Info, 2016, https://www.gandul.info/stiri/rezultatelefinale-la-alegerile-locale-2016-in-bucuresti-si-in-tara-15467542.

45 Save Romania Union, The Charter of USR Values, 2016.
} 
ALDE was formed around the personality of its leader Tăriceanu. Although the party had two co-presidents until 2017, each leader of the two former entities (PLR and PC) that merged to form ALDE, the de facto leader has always been Tăriceanu. He was a constant presence in Romanian politics since 1990, when he was one of the main politicians in the reviving of the PNL; the latter is a historic party with an interrupted presence during communism, brought back to life after the regime change. The reason to leave the PNL and create his own party is related to the Liberals' decision to withdraw the government coalition at the beginning of 2014. Tăriceanu favored the continuity of the agreement with the social democrats and convinced a few Liberal parliamentarians to join his cause. The splinter took shape around his ambitions as a top career politician and he was rewarded for his loyalty by the social democrats: ALDE was included in the government immediately after its official formation and received four ministers. In 2016, ALDE was again involved in government, after joining forces with the same social democrats, to maintain its political influence. Through the formation of ALDE and support provided to the social democrats Tăriceanu received personal reward by being elected the Speaker of the Senate in March 2014, a few weeks after leaving PNL. He was still in office at the time when this article was written (September 2019).

The personal appeal and decisions of Tăriceanu were vital for the party. To begin with the appeal, the splinter from the PNL created an intra-parliamentary party due to the parliamentarians who followed Tăriceanu. He has constantly promoted the idea that his new party (initially PLR and later ALDE) is a closer version to liberalism than the PNL. The party statute in 2017 explicitly argues in Art. 5 that "it is the legitimate successor of modernizing and reforming liberalism, which constructed modern Romania" and in Art. 6 that "ALDE assumes the history and tradition of liberalism in Romania, the representation of liberal ideas and values" ${ }^{46}$

Tăriceanu's strategy to appeal the Liberal voters and elites is clearly outlined in his speeches. For example, in 2016, he argued that his intention was "to make it clear to citizens, voters, that ALDE is the true representative of liberalism in Romania. A party that justifies the defense of individual rights and freedoms and of course all the other components that have

\footnotetext{
${ }^{46}$ Alliance of Liberals and Democrats in Romania, ALDE Statute.
} 
a liberal view on things" ${ }^{47}$ In 2018, the message was more direct: "The reunification of liberals must be around the fundamental liberal values represented by ALDE. So those who are in the PNL and believe that these are the defining values of liberalism and they think themselves liberal, are certainly welcome in ALDE". 48 Through his actions, Tăriceanu determined a clear association of ALDE with his image. He has always been the center of all political negotiations on behalf of the party and his personal statements were reflected in the vote of ALDE parliamentarians.

The PMP has a very similar story with its formation strongly associated with one individual. The party was formed by Băsescu's close supporters who were defeated in PDL's internal elections. Like ALDE, this is a splinter from a major party that took shape around the personality of a prominent leader with long experience in politics. Another similarity is that his was also an intra-parliamentary party that had the advantage of having formed PDL parliamentarians joining its ranks and thus the advantage of more funding in the 2016 elections. ${ }^{49}$ Unlike ALDE, Băsescu's appeal in the case of PMP was not moderated, although it could not officially occupy the leading chair. According to the Romanian Law, the president cannot be a party member while in office. For these reasons, when his supporters left the PDL, Băsescu was prepared to lead the newly created party. In June 2013, Băsescu declared his intentions and publicly introduced the party: "I would like that, after I finish (the presidential term), besides the fact that I will take care of the People's Movement, I will support the People's Movement Party efficiently, because now I cannot support it" .50

His term in office as country president ended in 2014 and he moved on to become the PMP party leader. ${ }^{51}$ Illustrative for this situation is a former PDL member' statement who joined the PMP and publicly declared: "I resigned from PDL on Friday and joined the PMP. I made this gesture to create real opposition to USL, to create a strong right wing and to

\footnotetext{
47 “Călin Popescu-Tăriceanu, Despre o Migraţie a Liberalilor La ALDE (Călin Popescu-Tăriceanu about a Migration of the Liberals to ALDE)," Antena 3, 2017, https://www.antena3.ro/politica/calin-popescu-tariceanu-despre-omigratie-a-liberalilor-la-alde-sunt-dispus-oricand-sa-stau-de-402424.html.

48 “Tăriceanu, Invitație Fățișă Pentru Membrii PNL Să Se Înscrie În ALDE (Tăriceanu Invites Directly the PNL Members to Join ALDE)," Digi 24, 2018, https://www.digi24.ro/stiri/actualitate/politica/tariceanu-invitatiefatisa-pentru-membrii-pnl-sa-se-inscrie-in-alde-974468.

${ }^{49}$ The Romanian Law of Party Funding allocates considerably more financial resources to parliamentary parties compared to those that do not have seats in the legislature.

50 "Traian Băsescu Îşi Face Partid (Traian Băsescu Forms a New Party)," Ziarul National, 2013, https://www.ziarulnational.md/traian-basescu-isi-face-partid-cum-se-descifreaza-pmp/.

${ }^{51}$ For all these reasons, we focus on Băsescu as the de facto leader of the party instead of Tomac who was there mainly as a cover.
} 
develop all the projects of president Traian Băsescu". ${ }^{52}$ Further evidence that this was Băsescu's political project is that eight of his presidential advisors joined the PMP immediately after its formation. ${ }^{53}$ The manifesto for the 2016 legislative elections centers on Băsescu and starts with a quote from him in which he claims "I will fight 10 more years". ${ }^{54}$ This is a direct reference to the time spent in office as country president.

USR was also formed around the personality and political appeal of its leader. Dan was well-known in the NGO world and a prominent figure among those that wanted a better urban planning of the capital city. In the 2012 local elections for mayor of Bucharest he ran as independent and adopted an anti-system rhetoric. He used this outsider position to promote his own party as a different one. His first party, i.e. USB at local level, was formed on image capital created as an independent candidate.

Unlike Tăriceanu and Băsescu who used their experience in politics and charisma as main image features, Dan built on his civic activist background, PhD in Mathematics at a prestigious university and on a more pragmatic approach to things - as opposed to the ideological rootedness of most other parties. All these were appealing to underrepresented cultural and economic segments of the population. ${ }^{55}$ Once his image was shaped at local level, the next step was the creation of a national level organization. His image was associated with the party, which strengthened USR'S credibility. Unlike the two party leaders discussed before, Dan created his party outside the legislature and did not benefit from the support of other parties' elites. On the contrary, USR denied the membership of politicians who belonged to other parties. The message Dan conveyed with his party was about a different way of doing politics, very similar to what he did as a candidate in the local elections.

The roles of these leaders in party formation are variations on the same theme of strong personalization. All three leaders used their image, personal appeal and popularity among the electorate to create a new party. There are several differences about how they proceeded. Tăriceanu and Băsescu used their extensive political experience, connections with

\footnotetext{
52 Mădălina Mihalache, "După Udrea, Şirul Demisiilor Din PDL Continuă (After Udrea, the Resignations from PDL Continue)," Adevărul.Ro, 2014, https://adevarul.ro/news/politica/Sirul-demisiilor-pdl-continua-alti-cinciparlamentari-1_52eb8755c7b855ff56f51a86/index.html.

53 George Arun, "Un Partid Își Caută Electoratul (A Party Looks for Its Electorate)," Deutsche Welle, 2014, https://www.dw.com/ro/un-partid-își-caută-electoratul/a-17395743-0.

54 People's Movement Party, "PMP Fights for Romania."

${ }^{55}$ Cosmin Dima, “David Și Goliat. Analiza Genezei Și a Succesului Electoral Al Uniunii Salvați România În Alegerile Locale Și Parlamentare Din 2016 (David and Goliath. The Analysis of the USR's Formation and Electoral Success in the 2016 Legislative Elections)," Revista Polis 5, no. 1 (2017): 171-97.
} 
parliamentarians and ideology to split from established parties and develop a separate organization. They relied on politicians who were dissatisfied with what they had in their old parties. Dan had very limited political experience and sought to develop a party based on ways of action and principles shaped as a reaction to existing political world. Rather than building on ideology, he presented himself as an outsider to politics and formed the party along similar lines.

\section{Different Approaches to Party Cohesion}

Since its formation, ALDE had no major internal conflicts or emerging factions, while the members provide extensive support to Tăriceanu. The latter handled with strong hand and swiftly the only internal dispute. This took place in 2017 when the party ended the coleadership situation and moved to a single leader. Tăriceanu and Constantin had different opinions about the new leader's election. Tăriceanu had a more conservative approach and, knowing his support among the party members, strived to keep the election procedure unchanged, as a party congress's function. The latter includes delegates from the territorial branches and elects the leader. Constantin promoted the idea of elections at all party levels. In particular, the leader was supposed to be elected through primaries. This is in line with the tendency of many West European parties to open up the leadership selection process and become more inclusive. However, in Romania such a practice has very limited popularity and some of the earlier attempts created more problems rather than solving the existing ones. ${ }^{56}$

Without many supporters in the party, Constantin failed. The ALDE executive committee decided, based on Tăriceanu's initiative, to withdraw the political support for Constantin who, as a result of this decision, lost his office as Minister of Environment. Furthermore, without political support from the party, Constantin could not run against Tăriceanu for leader in the forthcoming congress. Tăriceanu got elected as party leader after a "coronation" (single candidate) with 1,065 votes in favor and 29 against. After the congress, the executive committee excluded Constantin and two of his supporters, members of the Romanian Parliament, from the party. Thus, any opposition and source of dissent in ALDE has been removed.

\footnotetext{
${ }^{56}$ Sergiu Gherghina, "One-Shot Party Primaries: The Case of the Romanian Social Democrats," Politics 33, no. 3 (2013): 185-95.
} 
The situation in PMP resembles to a great extent what happened in ALDE with two important exceptions. First, the party cohesion was provided by Băsescu's leadership, initially on the side due to incompatibility with his presidential position, and afterwards as a party leader. Second, the cohesion was ensured through charismatic appeal more than through a strong hand approach. Since the party was formed by his group of supporters, its homogeneity is high and durable. Like Tăriceanu in ALDE, Băsescu excluded any prominent members that raised their voice against his domination (e.g. in December 2014 the PMP vicepresident and Member of the European Parliament). The high level of support for Băsescu and the dependence of the party's cohesion on him were visible at the 2016 party congress when the PMP members refused to accept any political strategy that does not involve Băsescu, many threatening to leave if he does not continue as leader to ensure political continuity. ${ }^{57}$

Not even the controversial merger with the National Union for the Progress of Romania, initiated by Băsescu in 2016 and failed by 2018, gave rise to any factions within the party. This was mainly because Băsescu adapted his rhetoric to mirror the dissatisfaction of many PMP members with this merger. As such, in 2018, he pushed to abandon the merger using arguments related to the lack of professionalism and involvement in the other party. Băsescu was a driving factor for cohesion, by keeping everything together even after stepping down as the party's official leader. In 2018, another leader was coronated, having Băsescu's full support, while he was elected honorary president. Băsescu continues to be associated with the party's image and remains deeply involved with the party. He was the top candidate for the European elections of 2019 and obtained sufficient electoral support to keep PMP in the European Parliament for another term in office.

The USR intra-party cohesion was ensured for its first year of existence by the adherence to common principles and values and by the electoral success obtained in 2016 . However, unlike Tăriceanu and Băsescu, Dan was not able to ensure the cohesion through his leadership style. His previous experience as activist within an NGO influenced his approach. The policies rather than the structure appeared to be the priority. Accordingly, party cohesion was considered a natural process that will develop along other organizational features. Dan

\footnotetext{
57 “Surpriză La Congresul PMP. Băsescu, Forțat Să Rămână Președinte (Surprise at the PMP Congress. Băsescu Forced to Remain President)," DCNews, 2016, https://www.dcnews.ro/surpriza-la-congresul-pmp-basescu-forat-sa-ramana-pre-edinte-deciziile-majore-amanate_501173.html?print=1.
} 
had no specific strategy about how to strengthen it. One reason for the absence of a strategy was the limited amount of resources, which were used to achieve other goals such as electoral support. Another reason is that Dan supported the idea of a multicultural party with a high level of autonomy for the local branches ${ }^{58}$, which often leads to lower intra-party cohesion as illustrated in the literature.

As soon as a different opinion took shape within the organization, Dan resigned. In June 2017 he left USR because the party's executives decided to oppose the Constitutional change against same-sex marriage. This difference of opinions was not the only thing that plagued the USR. Under Dan, a political faction started having control over the party, which created internal tensions. The caretaker party leader, Elek Levente explained that: "When we start the meeting of the National Executive (BN) the decisions are already taken in the small group and the votes decided. The decision process in the BN has unfortunately becomes a formality. In this party everything is traded. Discordant or critical opinions are muffled by this group that speaks over us, and these are no longer mentioned in the transcript that appears late and is well curated, so that there seems to be a consensus". ${ }^{99}$ In October 2017, Dan Barna was elected president, after a process that divided the party. The supporters of Dan wanted a different candidate and when he withdrew from the race, they launched allegations regarding the way intra-party elections were organized. Barna was re-elected as president in September 2019 after internal primaries that further divided the party with accusations of fraud coming from several opponents.

The three parties have different approaches to intra-party cohesion. ALDE is leadercentered, with strong cohesion and directly determined by his control and decisions. PMP does not always have its leader formally in office but his connections and influence keep the core of members united. In both parties, the leaders rule with a strong hand and remove any elements of dissent in preliminary stages, before factions forming that could endanger cohesion. USR is the example of a party in which its initial party leader did not pursue intraparty cohesion and he gave up his position as soon as different opinions emerged. The internal

\footnotetext{
58 Digi 24, "Nicușor Dan Și Clotilde Armand Recrutează Candidați La Parlamentare (Nicusor Dan and Clotilde Armand Recruit Parliamentary Candidates)," 2016, https://www.digi24.ro/stiri/actualitate/politica/nicusor-dan-si-clotilde-armand-recruteaza-candidati-laparlamentare-547686.

${ }^{59}$ Ernest Manzac and lulia Rosu, “Am Întrebat Membri USR Și PLUS de Ce Le Pleacă Oamenii (We Asked the USR and ALDE Members Why Their People Leave)," Vice.Com, 2019, https://www.vice.com/ro/article/43jyqw/dece-pleaca-oameni-de-la-usr-plus.
} 
rivalry and contestation were formed during his term in office but came to surface quite prominently after he stepped down.

\section{The Effects on Party Membership}

The statutes of the three political parties conceptualize membership similarly in terms of conditions to become a member, rights, responsibilities and termination of membership. ${ }^{60}$ Figure 1 includes the evolution of membership in the three parties. The data comes from party headquarters and show a continuous increase of membership between party formation and present. ${ }^{61}$ This time frame allows us to compare what happened before and / or after the leaders of PMP and USR stepped down (the ALDE leader is unchanged). Some increases are steeper than others and there are important differences in terms of the membership appeal pursued by the three leaders investigated here.

ALDE started off in 2015 with slightly more than 30,000 members out of which many were former Liberal members who followed Tăriceanu. The following two years the party almost tripled its membership mainly due to two causes. First, the party leader made an attempt to field as many candidates in local elections as possible and for that the party needed territorial units across the country. ALDE got third on the 2016 local elections with roughly $6.5 \%$ of the vote and continued its good performance in the general elections, passing the $5 \%$ electoral threshold. Second, the presence in Parliament and subsequently in government could have been an incentive for people to join the party. The Liberals had poor results in the legislative elections and ALDE had the potential to attract disillusioned people. At the same time, the party attracted opportunists who tried to use the presence in government to their own advantage. The growth in 2018 and 2019 has been quite steep and is probably associated to the interest of the party leader for large membership. When he was the leader of the Liberals, the party also had an increase in membership.

\footnotetext{
${ }^{60}$ Alliance of Liberals and Democrats in Romania, ALDE Statute; People's Movement Party, PMP Statute; Save Romania Union, USR Statute, 2017.

${ }^{61}$ Earlier research indicates that membership rolls communicated by party headquarters tend to be exaggerated. In the case of ALDE, PMP and USR, these are the only available sources. There are some numbers in the media, but these also come from the headquarters. While the veracity of these numbers cannot be checked, it is very good for our longitudinal analysis that they come from the same sources. In case there is a bias, this is systematic and is likely to occur at all moments in time, which does not affect the quality of our analysis (i.e. we are interested in trends over time). This would have been much more problematic for a cross-party comparison.
} 
Figure 1: The Evolution of Membership in the Three Parties (2013-2019)

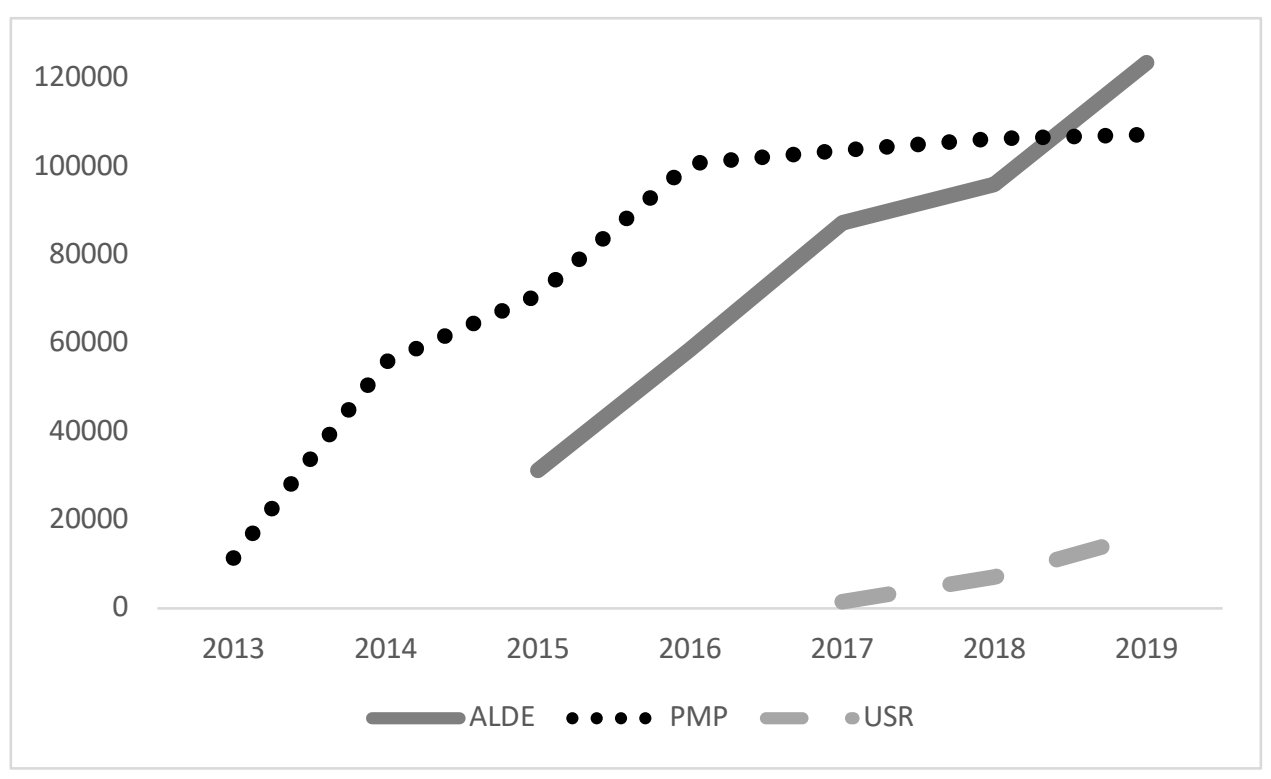

The PMP started with a small organization of roughly 11,000 members but quickly enlarged it to more than 55,000 in one year after formation. The appeal of Băsescu and the alternative that this party provided to the Democrat Liberals that merged with the Liberals were among the drivers for this boost of membership. During his term in office (2015-2018), the membership of the PMP reached approximately 100,000 members and stabilized around that value until 2019. This is a high number for the Romanian parties with only two other parties having more members. In essence, Băsescu was oriented towards a large and stable organization, similar to what the Democrat Liberals had when he acted as country president. In addition to the electoral benefits of a large membership (i.e. mobilization and recruitment pool for candidates), this was also a way to reflect the support he has after the split from the Democrat Liberals.

The USR under Dan did not pursue to create and expand a large membership structure. He did not have much time to establish a national organization since he resigned less than one year after formation. In that time span little attention was paid to members and to means of increasing the membership. The policy was determined by the members' quality, rather than their number, according to a public statement ${ }^{62}$. Moreover, the high refusal rate

\footnotetext{
62 Digi24, “Nicușor Dan Și Clotilde Armand Recrutează Candidați La Parlamentare.”
} 
for new members (over $50 \%$ ) was used as a marketing tool. ${ }^{63}$ As such, the party maintained a minimal organization that had roughly 1,500 members one year after its creation. ${ }^{64}$ The rigid admission process, the lack of an official membership policy and the resource investment in campaigns illustrate that Dan had little interest in expanding the membership.

After Barna became party leader, a specialized department for expansion was formed, with several key objectives among which the increase of membership and territorial coverage. By 2018 the number of members increased to around 7,000 members ${ }^{65}$ and later to 16,751 at the September 2019 primaries for the selection of party leadership. This membership boost was the result of several recruitment and public consultation campaigns in which voters were involved.

\section{Discussion and Conclusion}

This article aimed to assess leaders' impact on the party formation, intra-party cohesion and membership organization between 2015 and 2019 in three newly formed parties in Romania. It applied theoretical insights derived from the literature to test the extent to which three leadership features can have an influence on these dimensions of party organization. Table 1 summarizes the impact of the three leaders, with several important similarities and differences to be observed between them. In terms of party formation, the personal appeal of all the three leaders was a crucial driver with one major difference between them. On the one hand, Tăriceanu and Băsescu personalized the party and used the elites from their previous parties (both of their new parties were splinters) to form a new organization. On the other hand, Dan created his party on new grounds and played the card of the newcomer. He presented himself as someone who came from outside politics and wanted to give a particular shape to his party. His party was for the first year associated with his name but did not push things in the direction of personalization.

\footnotetext{
${ }^{63}$ Iulia Marin, "Nicușor Dan: 'Nu Ne Asumăm Riscul Unei Alianţe Pentru Alegerile Parlamentare (Nicusor Dan: We Do Not Assume the Risk of an Alliance for Parliamentary Elections),'” PressOne, 2016, https://pressone.ro/nicusor-dan-nu-ne-asumam-riscul-unei-aliante-pentru-alegerile-parlamentare.

64 USR, "Raport Despre Starea Extinderii (Report about the Status of Expansion)," 2019, 2, http://www.cristianghinea.ro/wp-content/uploads/2019/07/Binder-USR-EXTINDERE-FINAL.pdf.

${ }^{65}$ USR, "Raport Despre Starea Extinderii (Report about the Status of Expansion)."
} 
Table 1: An Overview of the Impact of the Three Leaders

\begin{tabular}{lccc}
\hline \multirow{2}{*}{ Formation } & Tăriceanu (ALDE) & Băsescu (PMP) & Dan (USR) \\
\cline { 2 - 4 } & $\begin{array}{c}\text { Personal appeal } \\
\text { Elite support }\end{array}$ & $\begin{array}{c}\text { Personal appeal } \\
\text { Elite support }\end{array}$ & $\begin{array}{c}\text { Personal appeal } \\
\text { Outside politics }\end{array}$ \\
\hline Intra-party cohesion & High & High & Low \\
& Strong hand & Charismatic appeal & Diversity of opinions \\
\hline Membership & $\begin{array}{c}\text { Steep increase } \\
\text { High priority }\end{array}$ & Large and stable & Minimal \\
& High priority & Low priority \\
\hline
\end{tabular}

The intra-party cohesion was approached quite differently by the three leaders. Tăriceanu and Băsescu pursued the homogeneity of their parties, without internal dissent and ensured it through particular means. Tăriceanu used a strong hand and punished the defectors, Băsescu used his charisma to keep the party together. Dan was not concerned by intra-party cohesion and he resigned at the first signs of dissent from members, roughly half a year from the USR's access to Parliament. A strong camp was formed within the party without much reaction from the leadership. In terms of membership, the three leaders had different approaches. Tăriceanu opted for a continuous and relative steep increase over the years. Băsescu was satisfied to reach a high level and maintain it there, while Dan had a minimal party membership base that was concentrated in the large cities. For Dan membership was not a priority for two potential reasons: without experience in politics he does not understand the benefits of broad membership and his focus was on policies rather than on structures.

These results illustrate that leaders can contribute decisively to the formation of new parties and to the shape of their organization. The three features tested in the analysis play important roles but the depicted image is quite nuanced. The personalization of power is important especially in the phase of party formation because the central figure of a leader can act as a catalyst. The various units have to be brought together and two of the leaders succeeded in doing that with the help of political elites, while the third solely with his personal appeal.

The personalization has limits when it comes to maintaining the cohesion of the newly assembled party. That is when the desire for control and other features of presidentialization make the difference. The two leaders who display high need for power and actively remove 
opposition within their party are also successful in achieving high levels of cohesion. This behavior can also be determined by the professional experience of the two leaders for ALDE and PMP, who are aware of what happens when divergent opinions are allowed. In fact, they may have learned from their political past in which political divisions in their previous parties led to their defection.

The most visible effect of political experience can be seen relatively to the development of a membership organization. Without political experience, the USR leader cannot see the benefits of an extensive cohort of rank and file. His approach, limited mainly to personalization, results in low levels of organizational development of the party. His political priorities are different from those of the two leaders who were high profile politicians and party leaders before forming the new parties. The two experienced leaders pursue the strategy to develop the membership organization because they have observed how members can contribute to medium and long-term electoral performance. Their previous parties were ranked second and third in terms of membership at national level when they left. This can also indicate a feature of socialization associated to their political experience: they had experience in parties with large membership organizations and wanted to continue that tradition when establishing new political competitors.

ALDE and PMP emerged after splinters from established parties and became vehicles of experienced politicians. USR was formed on the bases of an NGO by a political leader with limited political experience. The origins of the parties can hardly explain the development of party organization. To begin with party formation, when factions split from an existing party it does not mean that they will automatically survive as separate parties in the political competition. For example, the PNL - the party from which ALDE split - has a very large number of splits throughout its post-communist existence. However, the vast majority of splinters either returned to the party or ceased to exist after a while. ${ }^{66}$ As such, the mode of formation and the mobilization of elite support for the creation of a new party rests in leaders' ability to persuade these elites about the viability of their new project. In brief, it is insufficient to be a splinter and have some political resources as long as the leadership style cannot use these resources. Both cases of ALDE and PMP illustrate that their leaders made effective and

\footnotetext{
${ }^{66}$ Gherghina, Party Organization and Electoral Volatility in Central and Eastern Europe: Enhancing Voter Loyalty.
} 
efficient use of their political experience in shaping a new avenue for the political elites who followed them.

The development of intra-party cohesion in these three parties is hard to connect with their origins. The splinters are often prone to low levels of cohesion because they have already dissented from another party. As such, the high levels of cohesion in the two splinter parties (ALDE and PMP) can be essentially attributed to the leadership styles. The same applies to Dan in USR who did not alter the decision-making process when shifting from civil society to political party. He focused on the diversity of opinions at the cost of cohesion. The leadership was also crucial for the development of membership organizations. It is true that the splinters do not start their membership organizations from scratch. However, their initial level of members does not guarantee an increase in their membership. For example, Figure 1 illustrates how the membership flattens out for the PMP from a certain moment in time. Without a leader oriented towards the development of membership, aiming to have a large base of rank-and-file, the number of members would continue to gravitate around that initial number with which they split. At the same time, the parties that emerge from civic movements - USR in our analysis - do not have a handicap in developing membership organizations. For example, Podemos in Spain has its origins in a social movement and registered more than 400,000 members in its initial months of existence. ${ }^{67}$

The implications of this qualitative analysis reach beyond the three political parties investigated here. It makes both theoretical and empirical contributions to the literature on the role of leaders in newly emerged political parties. At theoretical level, the article shows that party leadership can shape the organizational development of newly formed parties. In particular, it identifies the strategies used by party leaders and links them with personalization, presidentialization and political experience. The insights provided by this analysis can be used to refine and expand the theories of party organization that have focused so far more on established parties. Our findings can form the grounds for a systematic analytical framework to understand the effects of leaders. The three dimensions for analysis suggested here are not context specific and they can be used in future research seeking to investigate other parties or countries.

\footnotetext{
67 Juan Rodríguez-Teruel, Astrid Barrio, and Oscar Barberà, “Fast and Furious: Podemos' Quest for Power in Multi-Level Spain," South European Society and Politics 21, no. 4 (2016): 561-85.
} 
The empirical contribution of this study lies in the identification of clear effects of leaders on the life of their parties. Our analysis looks at the political parties emerged in postcommunist Romania more than two decades after the regime change, in a political environment characterized by cartelization and relatively hostile to new parties. In this context, the results confirm existing theories such as the importance of charismatic leadership for intra-party cohesion ${ }^{68}$ but nuance it by providing details about how three features of leadership - more fine-grained than charisma - can interact to produce various outcomes. Our findings indicate that the leaders' features are one of the potential explanations for which political parties perish or persist on the political arena.

This article also brings empirical evidence to distinguish between the effects of a leader on the party organization. Instead of treating the latter as a monolith and considering that leaders have a consistent impact on organization, the article differentiates between three components. Accordingly, the results show that leaders can be catalysts of swift formation but their approach could pay less attention to intra-party cohesion or undermine the development of member organizations. All these have consequences for the existence of the party long time after the leader is gone. Finally, the article illustrates the existence of different avenues to pursue similar goals: e.g. high intra-party cohesion can be achieved either through charismatic appeal or through high levels of control.

Future research can build on these findings and seek to refine theories of leaders' effects on party organization. The three features presented in this study can be complemented by others or, alternatively, the universe of cases expanded further. The number of newly emerged parties increases continuously in post-communist Europe and one avenue for research would be longitudinal or cross-country comparisons. The longitudinal comparison can contrast the behavior of first party leaders of new parties emerged at different moments in time in the same country. In the specific context of Eastern Europe, the analysis can use parties emerged in different decades of post-communism. The cross-country comparisons could provide important insights into how these effects vary across institutional settings, which could not be controlled with our study within the same party system. Another avenue for further research could be the use of semi-structured interviews with party elites and members to understand the ways in which these effects are perceived by those directly

\footnotetext{
68 Panebianco, Political Parties: Organization and Power.
} 
involved in the everyday life of the party. This type of data could substantiate the findings and link the analysis to real-life developments in the life of newly emerged parties. 